\title{
Impact of Different Land-Use Systems on Soil Physicochemical Properties and Macrofauna Abundance in the Humid Tropics of Cameroon
}

\author{
Lawrence Tatanah Nanganoa $\left(\mathbb{D},{ }^{1}\right.$ Justin Nambangia Okolle, ${ }^{2}$ Valentine Missi, ${ }^{2}$ \\ Jacques Roberto Tueche, ${ }^{3}$ Lewis Dopgima Levai $\mathbb{1},{ }^{4}$ and Jetro Nkengafac Njukeng ${ }^{5}$ \\ ${ }^{1}$ Department of Soil, Water and Atmosphere, Institute of Agricultural Research for Development (IRAD), Ekona, PMB 25 Buea, \\ South-West Region, Cameroon \\ ${ }^{2}$ Entomology-Nematology Unit, Institute of Agricultural Research for Development (IRAD), Ekona, PMB 25 Buea, \\ South-West Region, Cameroon \\ ${ }^{3}$ Department of Soil, Water and Atmosphere, Institute of Agricultural Research for Development (IRAD), Nkolbisson, \\ P.O. Box 2123, Yaounde, Centre Region, Cameroon \\ ${ }^{4}$ Biotechnology Unit, Institute of Agricultural Research for Development (IRAD), Ekona, PMB 25 Buea, \\ South-West Region, Cameroon \\ ${ }^{5}$ Rubber Programme, Institute of Agricultural Research for Development (IRAD), Ekona, PMB 25 Buea, \\ South-West Region, Cameroon
}

Correspondence should be addressed to Lawrence Tatanah Nanganoa; tatanah2002@yahoo.fr

Received 9 September 2018; Revised 7 January 2019; Accepted 27 January 2019; Published 27 February 2019

Academic Editor: Claudio Cocozza

Copyright (c) 2019 Lawrence Tatanah Nanganoa et al. This is an open access article distributed under the Creative Commons Attribution License, which permits unrestricted use, distribution, and reproduction in any medium, provided the original work is properly cited.

\begin{abstract}
The impact of different land-use systems on some soil physicochemical properties and macrofauna abundance in the humid tropics of Cameroon was studied. The land-use types included secondary forest (SF), oil palm plantation (PP), banana plantation (BP), sugarcane plantation (SP), and rubber plantation (RP). Soil particle size distribution, bulk density (BD), pH, organic matter $(\mathrm{OM})$, and number of macrofauna were evaluated. The results showed that OM and number of macrofauna were higher in the SF than in the other land-use types. Pearson's correlation analysis carried out to determine the relationship between OM and BD showed that $\mathrm{OM}$ and $\mathrm{BD}$ was strongly negatively related with correlation coefficient of -0.9653 . It also showed a strong significant negative correlation between $\mathrm{BD}$ and ants population $(r=-0.8828)$ and between soil $\mathrm{pH}$ and number of earthworms $(r=-0.9072)$. Based on the results, the SF produced more organic matter and higher number of macrofauna. However, the OM of the other land uses was not low; hence, it could be beneficial to return plant residues to the field for maintaining soil quality.
\end{abstract}

\section{Introduction}

Environmental degradation caused by inappropriate land use is a worldwide problem that has attracted attention in sustainable agricultural production systems [1]. The productivity and sustainability of soil depends on dynamic equilibrium among its physical, chemical, and biological properties [2]. These properties are continuously influenced by land uses. According to Di et al. [3], agricultural management practices can largely influence the quality of the soil which in turn is intrinsically linked to the sustainability of agroecosystem functions and productivity. Therefore, successful agriculture requires the sustainable use of soil resources as soil could easily lose its quality and quantity within a short period of time [4]. Soil health maintenance is essential for sustained food productivity, the decomposition of wastes, storage of heat, sequestration of carbon, and the exchange of gases. Since 1945, it is estimated that $38 \%$ of the cultivated areas in the world have been degraded. Annually, approximately 24 billion tons of topsoil is lost. This is 
equivalent to about 9.6 million hectares of land. Therefore, soil degradation and/or changes in soil quality that result from wind and water erosion, salinization, losses of organic matter and nutrients, or soil compaction are of great concern in every agricultural region in the world [5]. In an attempt to reverse the trend of declining soil quality, recent studies have focused on identifying suitable soil management practices. However, soil quality cannot be directly measured, and soil quality information is usually deduced from observed or modelled soil physical, chemical, or biological attributes $[6,7]$. Within the context of agricultural production, Karlen et al. [8] attributed high soil quality to be equivalent to longterm high productivity and the system resiliency without significant soil or environmental degradation [3]. Larson and Pierce [9] outlined five soil functions that may be used as criteria for judging the soil quality: to hold and release water to plants, streams, and subsoil; to hold and release nutrients and other chemicals; to promote and sustain root growth; to respond to management and resist degradation; and to maintain suitable soil biotic habitats.

Macrofauna found in soil and surface litter are known to play a central role in soil processes such as nutrient cycling, organic matter decomposition, and improvement of physical attributes such as aggregation, porosity, and water infiltration $[10,11]$. These small organisms, such as insects and other invertebrates, play a vital role in the production and maintenance of healthy soils, and therefore are key elements in the development of sustainable agriculture and forestry [12].

Human activities frequently cause the degradation of soil environment which leads to reduction in the number of animal and plant communities, where species able to bear stress predominate and rare taxa decrease in abundance or disappear [13]. With continuous cultivation, physical properties and productivity of many soils commonly decline due to decrease in organic matter content and soil $\mathrm{pH}$ [14]. Changes in soil properties caused by cultivation and management and their consequences to soil productivity have generated significant research concern for many years [15]. Information on the effects of land management on soil physicochemical properties and upon soil invertebrate communities under different land-use systems in the humid tropics of Cameroon is scanty and thus makes it difficult to recommend or adopt appropriate soil conservation and management practices. The objective of this study was therefore to evaluate the land-use effects on selected soil physicochemical properties and macrofauna abundance.

\section{Materials and Methods}

2.1. Study Site and Soil. For the purpose of this study, five different land-use systems were selected in Fako Division in the Southwest region of Cameroon known for intensive agricultural production. This area is characterized by two main seasons: the rainy season from mid-March to midNovember and the dry season from mid-November to midMarch [16]. It has a temperature ranging between $20^{\circ} \mathrm{C}$ and $28^{\circ} \mathrm{C}$ and annual rainfall of about $3000-5000 \mathrm{~mm}$. The area is composed of undulating high and low lands with many rocks and gravels due to volcanic eruptions. The land-use types include secondary forest (SF), banana plantation (BP), oil palm plantation (PP), and sugarcane plantation (SP), all located in Buea subdivision and rubber plantation (RP) in Muyuka subdivision. The exact locations of the fields and soil types are presented in Table 1. The soils in BP, PP, SP, and SF belong to the Mussaka series and RP to the Ekona series. Soils in these areas are formed on older mudflows and have a well-developed argillic horizon. They belong to one and the same continuum, with properties which are changing gradually [17].

2.2. Description of Land Use. The secondary forest was surrounded by oil palm plantation, cocoa farm, and other mixed cropping farms consisting of plantains, cassava, and cocoyams. The banana plantation is owned by the Cameroon Development Corporation (CDC) and was established from 2004 to 2007. Several agronomic/agricultural practices are employed, and these include periodic application of agrochemicals (insecticides, nematicides, fungicides, herbicides, molluscicides, and different kinds of fertilizers and lime), leaf and sucker pruning as well as the use of understorey irrigation system. Field residues (pseudostems, premature fruits, and leaves) and postharvest residue (penducles) are left to rot in the field. The oil palm plantation is also owned by CDC with oil palms that were planted since the year 1985 . Field residues (harvested fronds and male inflorescence) are left to rot in the farm. Unlike the banana plantation, the farm was under fallow for 6 months. The sugarcane plantation belongs to a smallholder farmer and was established in 1986. Agrochemicals were never used, and pruned leaves were the only field residues found in the farm. The rubber plantation is cultivated by the CDC, and the farm was established in 1984. The only farm residues were litter falls.

2.3. Soil Sampling, Processing, and Physicochemical Analysis. In all the sites selected, for soil sampling, the aforementioned crops were grown as the sole crops in the different land-use systems. The factors considered before choosing the sites were all the land-use systems were of the same soil type (volcanic soil), have similar climatic conditions, and operate within the same soil-forming factors.

2.3.1. Physicochemical Properties. In October 2016, undisturbed soil samples were collected in triplicate from each land use, per field per depth at $0-5 \mathrm{~cm}, 5-10 \mathrm{~cm}, 10-15 \mathrm{~cm}$, and $15-20 \mathrm{~cm}$ with a $100 \mathrm{~cm}^{3}$ cylinder for bulk density studies. A soil auger was used to collect composite soil samples for the study of $\mathrm{pH}$, particle size distribution, and organic matter contents. Bulk density was determined according to Blake and Hartge [18]. The values for the 0$20 \mathrm{~cm}$ soil layer were obtained from the mean of $0-5 \mathrm{~cm}$, $5-10 \mathrm{~cm}, 10-15 \mathrm{~cm}$, and $15-20 \mathrm{~cm}$. The organic matter contents were determined by the loss on the ignition method and the soil particle size distribution for each sample by the pipette method according to Gee and Bauder [19], from 
TABLE 1: Description of sampling sites used for the study.

\begin{tabular}{lccccrr}
\hline No. & Land-use type & Location & Longitude & Latitude & Elevation $(\mathrm{m})$ & Soil type \\
\hline 1 & RP & Mile 29 & $04^{\circ} 14.787^{\prime}$ & $009^{\circ} 21.876^{\prime}$ & 195 & Volcanic soil \\
2 & PP & Bowanda & $04^{\circ} 10.671^{\prime}$ & $009^{\circ} 19.900^{\prime}$ & 365 & Volcanic soil \\
3 & SP & Moli & $04^{\circ} 11.640^{\prime}$ & $009^{\circ} 18.681^{\prime}$ & 516 & Volcanic soil \\
4 & SF & Mussaka & $04^{\circ} 10.371^{\prime}$ & $009^{\circ} 19.623^{\prime}$ & 371 & Volcanic soil \\
5 & BP & Mussaka & $04^{\circ} 11.429^{\prime}$ & $009^{\circ} 19.281^{\prime}$ & 487 & Volcanic soil \\
\hline
\end{tabular}

RP, rubber plantation; PP, oil palm plantation; SP, sugarcane plantation; SF, secondary forest; BP, banana plantation (all the plantations are monocultures).

which the soil textural classes were obtained. Soil $\mathrm{pH}(1: 2.5$ $\mathrm{w} / \mathrm{v}$ soil/water ratio) was determined using a $\mathrm{pH}$ meter.

2.4. Macrofauna Sampling and Data Collection. The humid forest zone has a large and diverse soil-associated fauna that strongly influence soil properties and development. Data on the invertebrate fauna composition on the different land-use systems were collected above ground and within soil/litter.

2.4.1. Above-Ground Data Collection. Ten different positions were selected randomly on the different sites, and a sweeping net was used to collect the organisms [20] found on the low vegetation (about $0.5 \mathrm{~m}$ above soil) found under the main vegetation. The sweep net was swept on the low vegetation, and the organisms captured inside the net were prevented from escaping by folding the opening of the sweep net immediately after sweeping. The different species of organisms captured were counted in situ according to the different species and recorded in a field hand book. This process was replicated three times on each selected position.

2.4.2. Litter/Below-Ground Sampling and Data Collection. This was done by random selection of different positions on the different land-use systems. A machete was used to till the upper surface of the soil at an area of $30 \mathrm{~cm} \times 30 \mathrm{~cm}$ and a depth of $2 \mathrm{~cm}$. The bulk of the tilled soil (together with the litters) was collected with hand covered by hand gloves and then placed inside labelled plastic bags. The openings of the plastic bags were sealed by tying it with a cord to prevent the soil organisms from escaping. This process was replicated ten times. The plastic bags containing the soil were transported to the laboratory of the Entomology/Nematology unit of the Institute of Agricultural Research for Development (IRAD) for counting and classification of the captured organisms. Samples for the macrofauna were taken from the same place where sampling for soil physicochemical analysis took place.

2.4.3. Counting of the Below-Ground Organisms. Each replicate of soil/litter samples carried to the laboratory was laid out separately on a plastic tray. Using an iron rod and a touch light, the soil samples were spread on a plastic tray and the organisms found within were placed on labelled small vials containing $70 \%$ alcohol. Each group of organisms was counted and then classified to at least the level of phylum, class, and order, although some were classified up to family or species level.
2.5. Statistical Analysis. One-way analysis of variance (ANOVA) was used to compare the effects of different landuse systems on soil physicochemical properties. Separation of the means of the soil properties was performed using the Tukey HSD test $(p<0.05)$. Correlations between macrofauna abundance and some selected soil physicochemical properties were determined by Pearson's correlation coefficient. For all the statistical analyses, JMP 5 statistical software was used.

\section{Results and Discussion}

\subsection{Physicochemical Properties in the Different Land-Use Systems}

3.1.1. Particle Size Distribution. The sand content recorded in sugarcane plantation was highest in the $0-20 \mathrm{~cm}$ layer followed by that of oil palm plantation, banana plantation, rubber plantation, and secondary forest whereas the silt content was found highest in the secondary forest followed by sugarcane plantation, rubber plantation, banana plantation, and then palm plantation. Generally, there were significant differences in the soil particle size distributions in the different land-use systems with the soil texture for oil palm plantation classified as clay soil, while banana plantation and rubber plantation ranged from clay to silty clay soils and sugarcane plantation and secondary forest ranged from silt loam to silty clay loam soils (Table 2).

3.1.2. Soil $p H$. The soil $\mathrm{pH}$ varied from $4.90-5.68$ in the different land-use systems (Table 2) with banana plantation having the highest soil $\mathrm{pH}$ and oil palm the lowest. This high $\mathrm{pH}$ of banana plantation might be attributed to the periodic application of lime (dolomite) in the field. With the exception of oil palm plantation, no significant difference was observed among the land-use systems. However, oil palms grow well in the $\mathrm{pH}$ range of 4.3-6.5. It was also reported that the most suitable soil texture for oil palm plantation is sandy clay and silty clay [21]. The soil pHs could be categorized as very strongly acidic for soils in oil palm plantation, strongly acidic for sugarcane plantation and secondary forest, and moderately acidic for rubber and banana plantations [22]. The majority of tropical soils are acidic. Acidic soils $(\mathrm{pH}<5.5)$ are widespread, especially in humid regions; they cover $30 \%$ of the world's total land area and $60 \%$ of the total area in the tropics [23]. The agricultural solution to acidic soils is therefore the application of lime to achieve $\mathrm{pH}$ favourable for most plants (5.5-7.5). 
TABLe 2: pH, sand, silt, and clay properties in different land-use systems.

\begin{tabular}{lccccc}
\hline Land use & $\mathrm{pH}$ & Sand $(\%)$ & Silt $(\%)$ & Clay (\%) & Textural class range \\
\hline RP & $5.66(0.18) \mathrm{a}$ & $3.51(1.21) \mathrm{bc}$ & $39.14(3.35) \mathrm{b}$ & $57.34(2.70) \mathrm{b}$ & Clay-silty clay \\
PP & $4.90(0.04) \mathrm{b}$ & $8.44(0.10) \mathrm{ab}$ & $18.76(0.65) \mathrm{c}$ & $72.80(0.74) \mathrm{a}$ & Clay \\
SP & $5.33(0.02) \mathrm{a}$ & $10.35(0.37) \mathrm{a}$ & $63.25(2.39) \mathrm{a}$ & $26.749(1.98) \mathrm{c}$ & Silt loam-silty clay loam \\
SF & $5.32(0.01) \mathrm{a}$ & $3.12(1.02) \mathrm{c}$ & $72.00(1.95) \mathrm{a}$ & $25.24(2.74) \mathrm{c}$ & Silt loam-silty clay loam \\
BP & $5.68(0.07) \mathrm{a}$ & $5.68(1.80) \mathrm{abc}$ & $33.77(4.82) \mathrm{b}$ & $60.35(5.97) \mathrm{ab}$ & Clay-silty clay \\
\hline
\end{tabular}

Mean values with standard errors within the parenthesis. Column entries followed by the same letters are not significantly different at $p \leq 0.05$. RP, rubber plantation; PP, oil palm plantation; SP, sugarcane plantation; SF, secondary forest; BP, banana plantation (all the plantations are monocultures).

3.1.3. Soil Bulk Density (BD). The bulk density at $0-20 \mathrm{~cm}$ in all land uses varied from $0.91-1.21 \mathrm{~g} / \mathrm{cm}^{3}$ with the trend of secondary forest $<$ oil palm plantation $<$ banana plantation $<$ rubber plantation $<$ sugarcane plantation with the mean values of $0.91,1.06,1.13,1.16$, and $1.21 \mathrm{~g} / \mathrm{cm}^{3}$, respectively. The results showed that bulk density varied significantly $(P \leq 0.05)$ among the land-use systems (Figure 1) except between sugarcane plantation and rubber plantation and between banana plantation and oil palm plantation. The highest bulk density was found in the soil under the sugarcane plantation followed by rubber and banana plantations. In contrast, the lowest bulk density was observed in the secondary forest followed by the palm plantation. The high bulk density of the croplands compared to the secondary forest might be as a result of intensive agricultural practices for croplands [24]. This is also consistent with the result of Oguike and Mbagwu [14]. Increase in bulk density as a result of conversion of forest to cultivated land is a reflection of the extent of soil degradation and has been demonstrated by many researchers [25]. High bulk density is an indicator of low soil porosity and soil compaction. It may cause restrictions to root growth and poor movement of air and water through the soil [26].

3.1.4. Soil Organic Matter (OM). Soil organic matter for all land-use types from $0-20 \mathrm{~cm}$ depth ranges from a minimum in rubber plantation (14.32\%) followed by sugarcane plantation (15.18\%), banana plantation (17.45\%), and oil palm plantation $(18.10 \%)$ to a maximum in secondary forest (20.37\%). The high OM in the forestland might be as a result of tree leaves, stems, barks, flowers, logs, and fruits. In addition, microorganisms, animals, and roots contribute to the increase of OM [27]. There were significant differences $(P \leq 0.05)$ among the OM content of the land-use types except between oil palm and banana plantations and between sugarcane and rubber plantations (Figure 2). The high OM content also recorded in $\mathrm{PP}$ and $\mathrm{BP}$ might be as a result of plant residues that are abundantly available and which are returned to the soil in these environments. Salehi et al. [28] reported that the effects of trees on soil properties occur mostly due to the increase of organic matter and the release of nutrients from it. Although the OM contents of soils under RP and SP were lower than those of SF, PP, and BP, the values were also high because the leaf litters of these plants are left to rot in the fields.

3.2. Classification of Organisms Collected. Of the total of 1579 individual organisms collected from both the sweep netting (810 individuals) and soil/litter extraction (769 individuals)

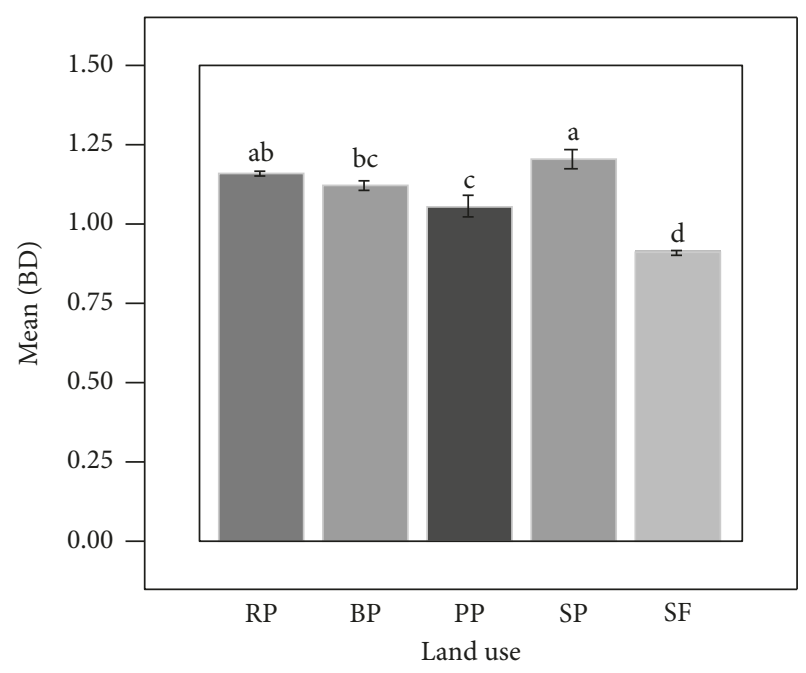

FIGURE 1: Effect of land-use change on soil bulk density (BD).

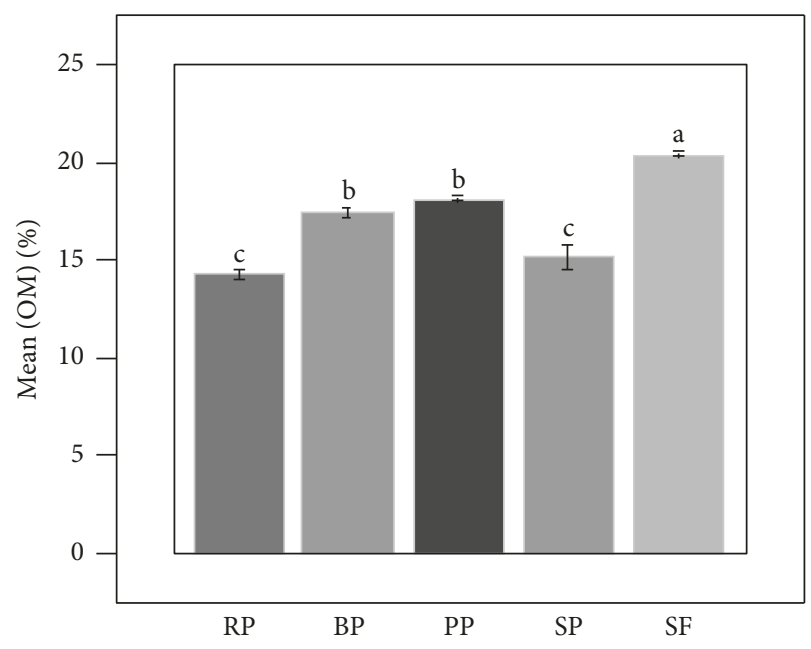

Figure 2: Effect of land use on soil organic matter.

(Figure 3), twenty-one (21) species were identified/classified up to class or order level while three (03) were unidentified (Table 3). The total numbers of individual organisms were highest in the forest and in the oil palm plantation and lowest in the sugarcane plantation. With respect to the different collection methods, highest number of individual organisms was recorded from soil-litter extracts in the forest. From sweep netting, the highest number of individual organisms captured was from the palm plantation (PP) (Figure 3). This may be due to the abundance and diversity of floral resources in the fallow oil palm plantation. 


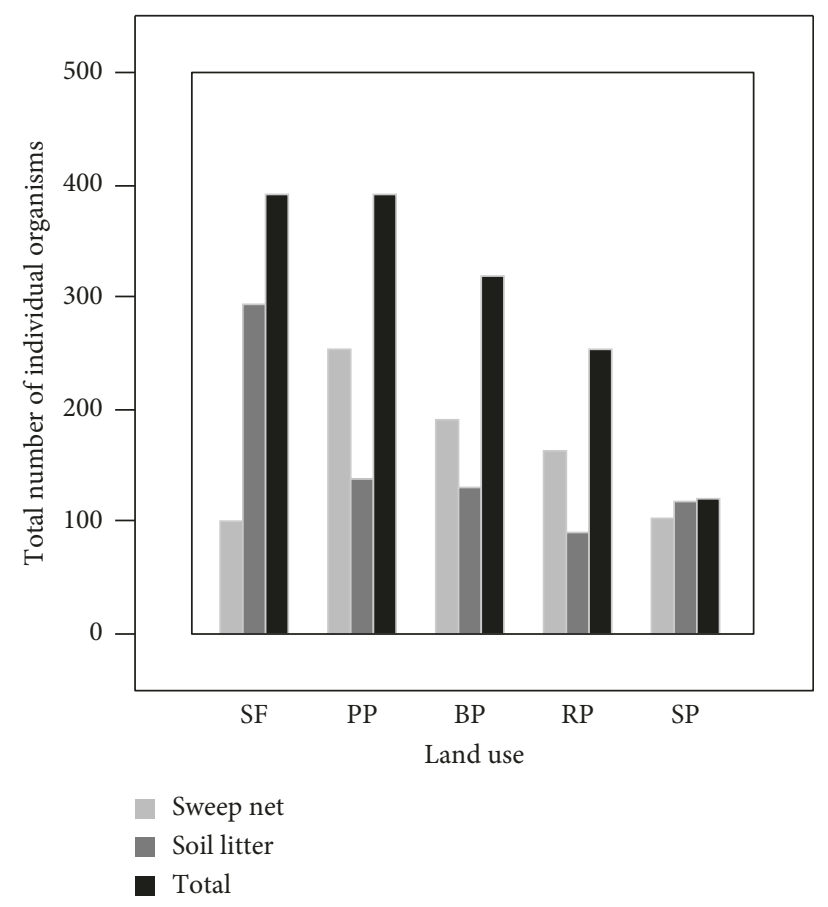

Figure 3: Total number of individual organisms collected from sweep nets and soil litter from different land-use systems.

TABle 3: Phylum, class, and potential role of species recorded from sweep nets and soil litter from different land-use systems in Fako Division, SW region, Cameroon.

\begin{tabular}{|c|c|c|c|c|c|}
\hline \multirow[b]{2}{*}{ Species/organisms } & \multicolumn{2}{|c|}{ Presence/absence } & \multirow[b]{2}{*}{ Phylum } & \multirow[b]{2}{*}{ Class (order) (family) } & \multirow[b]{2}{*}{ Potential ecological role } \\
\hline & $\begin{array}{c}\text { Sweep } \\
\text { net }\end{array}$ & $\begin{array}{c}\text { Soil } \\
\text { litter }\end{array}$ & & & \\
\hline Ants & Present & Present & Arthropoda & Insecta (Hymenoptera) (Formicidae) & Predation, soil fertility \\
\hline True flies & Present & Absent & Arthropoda & Insecta (Diptera) (Muscidae) & $\begin{array}{l}\text { Pollination, decomposer, soil } \\
\text { fertility }\end{array}$ \\
\hline Spider & Present & Present & Arthropoda & Arachnida (Araneae) & Predation \\
\hline Fruit flies & Present & Absent & Arthropoda & Insecta (Diptera) (Tephritidae) & Pest \\
\hline Beetle/weevils & Present & Absent & Arthropoda & Insecta (Coleopter) & Pest, soil fertility \\
\hline Cricket & Present & Present & Arthropoda & Insecta (Orthoptera) & Pest \\
\hline Wasp & Present & Absent & Arthropoda & Insecta (Hymenoptera) & $\begin{array}{c}\text { Predation, parasitoidism, } \\
\text { pollination }\end{array}$ \\
\hline Grasshoppers & Present & Present & Arthropoda & Insecta (Orthoptera) & Pest \\
\hline Termites & Present & Present & Arthropoda & Insecta (Isoptera) & Pest, soil fertility \\
\hline Cicada & Present & Absent & Arthropoda & Insecta (Hemiptera) & Pest \\
\hline Bugs & Present & Absent & Arthropoda & Insecta (Homoptera) & Pest \\
\hline Mosquito & Present & Absent & Arthropoda & Insecta (Diptera) (Culicidae) & Pest \\
\hline Caterpillar & Present & Absent & Arthropoda & Insecta (Lepidoptera) & Pest \\
\hline Millipede & Present & Present & Arthropoda & Diplopoda & Soil fertility \\
\hline Snail & Present & Present & Mollusca & $\begin{array}{l}\text { Gastropoda (Achatinidae) (mainly } \\
\text { Limicolaria spp) }\end{array}$ & Pest \\
\hline Centipede & Absent & Present & Arthropoda & (Chilopoda) & Predation \\
\hline Cockroach & Present & Absent & Arthropoda & Insecta (Blattodea) & Pest \\
\hline Moth & Present & Absent & Arthropoda & Insecta (Lepidoptera) & Pollinator \\
\hline Earthworm & Absent & Present & Annelida & Oligochaeta & Soil fertility \\
\hline $\begin{array}{l}\text { Unidentified unknown } \\
\text { insect larva }\end{array}$ & Absent & Present & Arthropoda & Insecta & Not known \\
\hline Earwigs & Absent & Present & Arthropoda & Insecta (Dermaptera) & Predation \\
\hline Slugs & Absent & Present & Mollusca & Gastropoda & Pest \\
\hline Unidentified insect & Absent & Present & Arthropoda & Insecta & Not known \\
\hline Unidentified arachnid & Absent & Present & Arthropoda & Arachnida & Predator \\
\hline
\end{tabular}


The total number of species recorded from the different land-use systems varied based on the collection methods used (Figure 4). From sweep netting, the highest number of species captured was from the sugarcane plantation (SP) and lowest from the forest (SF), while from the soil-litter extraction, the highest number of species was from forest and lowest from sugarcane plantation. Rossi and Blanchart [11] mentioned that tropical forests have higher densities of soil macrofauna compared to cultivated lands. This high number of soil macrofauna for the forestland might be as a result of its high organic matter content. This argument was strengthened by the fact that forestlands have a greater diversity and availability of food substrate for the soil fauna, fueled by high cycling of leaves and twigs in the forest litter [29]. According to Neeher [30], plant directly affects soil biota by generating inputs of organic matter above- and below-ground and indirectly by the physical effects of shading, soil protection, and uptake of water and nutrients by roots. In the forest, there is usually intense cycling of fine roots in the surface layer, which contribute as a nutrient substrate for soil fauna, thus favoring their multiplication. Rossi and Blanchart [11] also showed that macroinvertebrate communities also respond to environmental disturbance induced by land-use management.

3.2.1. Proportion of the Organisms Collected. First, the 24 species recorded were from three animal phyla: arthropoda, annelida, and mollusca. Majority of these species were arthropods $(88 \%)$ and then mollusks and annelids ( $8 \%$ and $4 \%$, respectively). Of this arthropod, the majority (81\%) were from the class Insecta, 9\% for Arachnida, and $5 \%$ each for Chilopoda and Diplopoda. The identified insects were from 10 orders, with most from the class Insecta (Table 3). Menedez and Cabrera-Davila [31] found out that of the over 7000 epigeous organisms collected from two different land-use systems, the predominant species were mainly insects particularly coleopterans and hymenopterans. All these show the importance of arthropods and most especially insects as biotic components in terrestrial ecosystems such as the ones in this research. Several reports have also shown the leading abundance of insects in natural and agroecosystems as well as their ecological role [11, 31-33].

\subsubsection{Potential Ecological Role of the Organisms Collected.} Generally, all organisms found in an ecosystem have ecological niches which include what they do in such a system. In this research, organisms recorded were also linked to certain ecological role in the land-use systems as a result of interactions within themselves or with other biotic and abiotic factors in the ecosystems. For the organisms in Table 3, the potential positive ecological role included predation, parasitoidism, improvement/maintenance of soil fertility, and pollination while the negative role is that some are pests. The proportion of these roles is shown in Figure 5, with pest having the highest (41\%), followed by predation and soil fertility improvement/maintenance (both $21 \%$

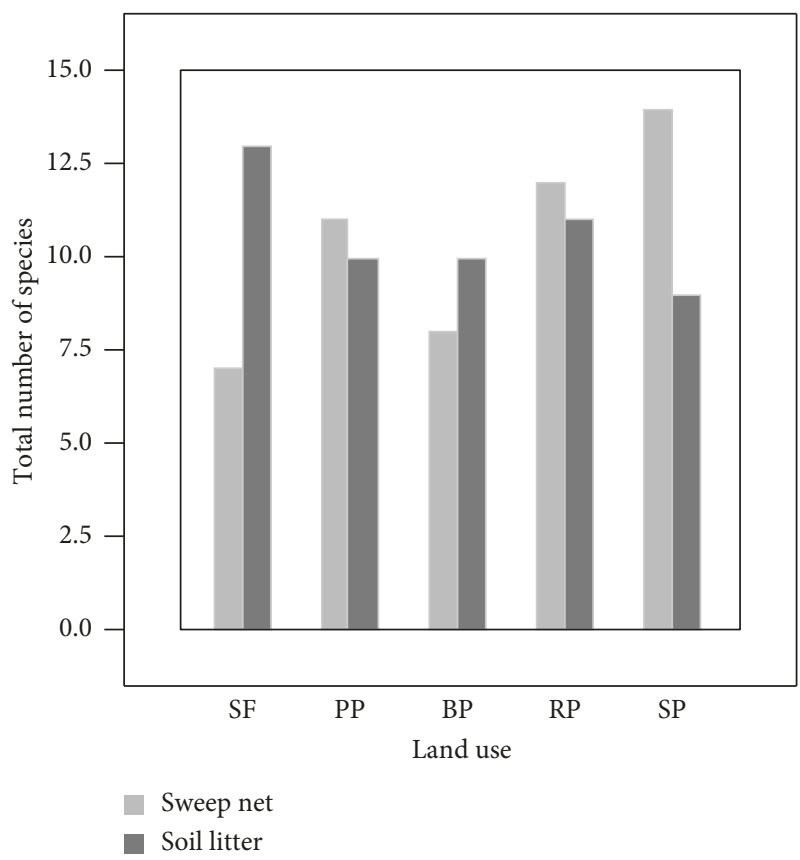

FIgURE 4: Total number of species captured from sweep nets and soil-litter extractions in the different land-use systems.

each), pollination and unidentified roles (each 7\%), and parasitoidism (3\%). Ponde et al. [33] showed that most animal and microbial groups are negatively affected by agricultural intensification.

3.3. Relative Abundance of Key Species. The key species were selected based on their potential role as environmental bioindicators and as pests, and these include earthworms, ants, beetles/weevils, snails, and spiders. For species captured in the soil litter, with the exception of relative abundance of snails (mainly Limicolaria species) and earthworms that were highest in the banana and palm plantations, respectively, the highest numbers of ants were from the forest (Table 4). Contrary to the case of snails, the total numbers of the other organisms were lowest in the banana plantations. This might be due to many different pesticides (including WHO class 1a pesticides such as terbufos and oxamyl) that have been or are being applied frequently in the banana plantations in the country [34]. Mongyeh et al. [35] and Okolle et al. [36] have reported the high impact of terbufos on mortality of banana borer weevils, ants, and earthworms. These chemicals therefore create an unfavourable environment, repelling and killing or affecting the reproductive capacity of especially the soildwelling organisms. Of recent, snails (Limicolaria $s p p$ ) have become serious problem on banana fruits in the plantations of Cameroon especially during the rainy season. Unlike the distribution cases of soil-litter organisms, the abundance of these organisms captured from sweep nets varied with respect to the different land-use systems (Table 4). Earthworms were not caught while the number of snails collected was few. Highest numbers of beetles and spiders were caught in the rubber plantation. Ants were highest in the SF and lowest 


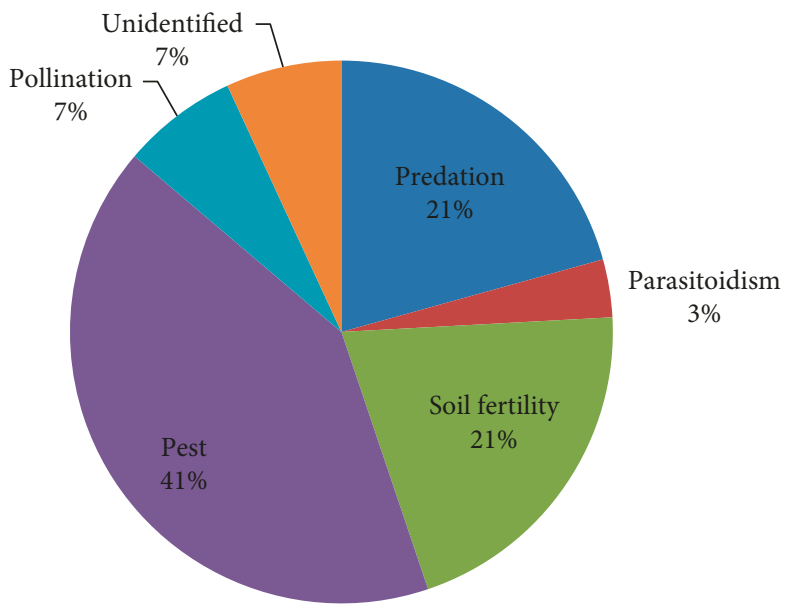

Figure 5: Proportion of potential ecological role of the organisms recorded.

TABLE 4: Relative abundance (\%) of key species collected from sweep net and soil litter on different land-use systems.

\begin{tabular}{|c|c|c|c|c|c|c|c|c|c|c|c|c|c|c|}
\hline \multirow{3}{*}{ Land use } & \multicolumn{2}{|c|}{ Earthworms } & \multicolumn{2}{|c|}{ Ants } & \multicolumn{2}{|c|}{ Beetles/weevils } & \multirow{2}{*}{\multicolumn{2}{|c|}{$\begin{array}{c}\text { Spiders } \\
\text { Abundance }\end{array}$}} & \multicolumn{2}{|c|}{ Snails } & \multicolumn{2}{|c|}{ Fruit flies } & \multicolumn{2}{|c|}{ Mosquitoes } \\
\hline & & & & & & & & & & & & & & \\
\hline & Sweep & Litter & Sweep & Litter & Sweep & Litter & Sweep & Litter & Sweep & Litter & Sweep & Litter & Sweep & Litter \\
\hline SF & 0 & 11.6 & 53.5 & 62.2 & 5.1 & 3.1 & 10.1 & 13.6 & 0 & 1.7 & 1.0 & 0 & 2.0 & 0 \\
\hline PP & 0 & 31.9 & 49.4 & 25.4 & 0.4 & 2.2 & 16.5 & 7.2 & 0 & 3.6 & 0 & 0 & 0 & 0 \\
\hline BP & 0 & 4.6 & 16.8 & 3.1 & 0.5 & 0 & 0.5 & 10 & 0 & 76.2 & 38.9 & 0 & 6.3 & 0 \\
\hline $\mathrm{RP}$ & 0 & 23.3 & 42.9 & 12.2 & 11.0 & 2.2 & 32.2 & 12.2 & 0 & 13.3 & 2.5 & 0 & 6.1 & 0 \\
\hline SP & 0 & 21.4 & 12.6 & 53.0 & 10.7 & 1.7 & 10.7 & 2.6 & 0 & 7.7 & 1.0 & 0 & 4.9 & 0 \\
\hline
\end{tabular}

TABLE 5: Pearson's correlation matrix of some selected soil physicochemical properties and macrofauna abundance.

\begin{tabular}{|c|c|c|c|c|c|c|c|c|c|c|}
\hline & $\mathrm{pH}$ & $\mathrm{OM}$ & $\mathrm{BD}$ & Earthworm & Ant & Beetle/weevil & Spider & Snail & Fruit fly & Mosquito \\
\hline $\mathrm{pH}$ & 1 & & & & & & & & & \\
\hline $\mathrm{OM}$ & -0.3163 & 1 & & & & & & & & \\
\hline $\mathrm{BD}$ & 0.325 & $-0.9653^{* *}$ & 1 & & & & & & & \\
\hline Earthworm & $-0.9072^{*}$ & 0.3603 & -0.4623 & 1 & & & & & & \\
\hline Ant & -0.5932 & 0.7643 & $-0.8828^{*}$ & 0.7838 & 1 & & & & & \\
\hline Beetle/weevil & 0.2904 & -0.132 & -0.097 & 0.128 & 0.2714 & 1 & & & & \\
\hline Spider & -0.5396 & 0.5922 & -0.6895 & 0.7843 & 0.8187 & 0.4089 & 1 & & & \\
\hline Snail & 0.5794 & 0.0254 & 0.1892 & -0.822 & -0.6187 & -0.5745 & -0.6229 & 1 & & \\
\hline Fruit fly & 0.5658 & 0.0639 & 0.1519 & -0.8061 & -0.5884 & -0.5786 & -0.5977 & $0.9993^{* *}$ & 1 & \\
\hline Mosquito & $0.9346^{*}$ & -0.4438 & 0.5246 & $-0.9552^{*}$ & -0.8085 & 0.0471 & -0.6438 & 0.727 & 0.7087 & 1 \\
\hline
\end{tabular}

${ }^{* *}$ Correlation coefficient is significant at the 0.01 level. ${ }^{*}$ Correlation coefficient is significant at the 0.05 level.

in the SP while spiders were highest in the RP but lowest in the BP. As for beetles/weevils, they were highest in the RP and lowest in the BP while fruit flies were highest in the BP. An interesting result was that mosquitoes (especially the tiger mosquitoes) were really high in the banana and rubber plantations. Irrigation water that usually settles on the banana stumps might be encouraging oviposition of these tiger mosquitoes.

3.4. Correlation between Soil Properties and Macrofauna Abundance. Correlation matrix of 10 variables representing various soil physicochemical properties and microfauna number under different land-use systems revealed significant correlation in 6 variable pairs out of fifty-five pairs
(Table 5). This result confirmed the strong significant negative correlation between $\mathrm{OM}$ and $\mathrm{BD}(r=-0.9653)$. The decrease of soil organic matter (OM) by the conversion of the forestland into cultivated fields probably caused the higher bulk density in the cultivated soils [37]. Hajabbasi et al. [38] reported that deforestation and subsequent tillage practices resulted in nearly $20 \%$ increase in bulk density and $50 \%$ decrease in soil organic matter for a soil depth of $0-$ $30 \mathrm{~cm}$ over 20 years in central Zagros. There was also a strong significant negative correlation between bulk density and ants population $(r=-0.8828)$. Cerdà and Jurgensen [39] in their work on the influence of ants on soil and water losses from an orange orchard in eastern Spain found that in antaffected soil, there was a reduction of soil bulk density, an increase in soil organic matter, and an increase in macropore 
flow as compared to soil without ant activity. Soil $\mathrm{pH}$ was negatively correlated with earthworms abundance $(r=-0.9072)$, indicating that at higher $\mathrm{pH}$, there is a decrease in earthworm number. Similar negative correlation was obtained by Karmegam and Daniel [40].

\section{Conclusion}

This study evaluated some selected physicochemical properties of soils and macrofauna abundance under different land-use systems (i.e., secondary forest and oil palm, banana, rubber, and sugarcane plantations) operating within the same soil forming factors and climatic conditions. Several soil physicochemical properties varied significantly among land uses. The results revealed that organic matter content might be as a result of quantity and type of plant residues that are returned to the soil in these environments. The number and diversity of soil/litter fauna were influenced by the type of soil management practiced in the different landuse systems. Negative significant correlations were observed between $\mathrm{pH}$ and number of earthworms and between ants and bulk density. Like the case of the banana plantation, excessive use of pesticides such as organophosphates has detrimental effects on ground dwelling organisms such as coleopterans, ants, and earthworms. Therefore, encouraging farmers to return agricultural residues (farm or processed residues) to rot in their fields could replenish degraded soil quality parameters for sustainable agricultural production and productivity in the study area.

\section{Data Availability}

The data used to support the findings of this study are included within the article. However, the corresponding author can be contacted for further information if needed.

\section{Conflicts of Interest}

The authors declare that there are no conflicts of interest regarding the publication of this paper.

\section{Acknowledgments}

This paper is based on the work carried out by the Department of Soil, Water and Atmosphere in collaboration with the Entomology-Nematology Unit within the framework of research activities of the Institute of Agricultural Research for Development (IRAD) funded by Public Investment Budget (BIP 12) of Cameroon in 2016.

\section{References}

[1] S. Ayoubi, F. Khormali, K. L. Sahrawat, and A. C. Rodrigues de Lima, "Assessing impacts of land use change on soil quality indicators in a loessial soil in Golestan province, Iran," Journal of Agricultural Science and Technology, vol. 13, pp. 727-742, 2011.

[2] J. Somasundaram, R. K. Singh, A. K. Parandiyal et al., "Soil properties under different land use systems in parts of Chambal region of Rajasthan," Journal of Agricultural Physics, vol. 13, no. 2, pp. 139-147, 2013.
[3] H. J. Di, K. C. Cameron, J. Shen et al., "The role of bacteria and archaea in nitrification, nitrate leaching and nitrous oxide emissions in nitrogen-rich grassland soils," in Molecular Environmental Soil Science, Xu and D. L. Sparks, Eds., pp. 79-89, Springer, Dordrecht, Netherlands, 2013.

[4] A. Kiflu and S. Beyene, "Effects of different land use systems on selected soil properties in South Ethiopia," Journal of Soil Science and Environmental Management, vol. 4, no. 5, pp. 100-107, 2013.

[5] X. Liu, S. J. Herbert, A. M. Hashemi, X. Zhang, and G. Ding, "Effects of agricultural management on soil organic matter and carbon transformation-a review," Plant, Soil and Environment, vol. 52, no. 12, pp. 531-543, 2006.

[6] R. Lal, "Managing world soils for food security and environmental quality," Advances in Agronomy, vol. 74, pp. 155-192, 2001.

[7] M. Kiani, G. Hernandez-Ramirez, S. Quideau et al., "Quantifying sensitive soil quality indicators across contrasting long-term land management systems: crop rotations and nutrient regimes," Agriculture, Ecosystems \& Environment, vol. 248, pp. 123-135, 2017.

[8] D. L. Karlen, E. G. Hurley, S. S. Andrews et al., "Crop rotation effects on soil quality at three northern corn/soybean belt locations," Agronomy Journal, vol. 98, no. 3, pp. 484495, 2006.

[9] W. E. Larson and F. J. Pierce, "Conservation and enhancement of soil quality," in Proceedings of IBSRAM Proceedings, vol. 2, pp. 175-20312, of Evaluation for Sustainable Land Management in the Developing World, Bangkok, Thailand, September 1991.

[10] J. M. Dangerfield and A. E. Milner, "Millipede fecal pellet production in selected natural and managed habitats of southern Africa: implications for litter dynamics," Biotropica, vol. 28, no. 1, pp. 113-120, 1996.

[11] J.-P. Rossi and E. Blanchart, "Seasonal and land-use induced variations of soil macrofauna composition in the Western Ghats, southern India," Soil Biology and Biochemistry, vol. 37, no. 6, pp. 1093-1104, 2005.

[12] N. E. Stork and P. Eggleton, "Invertebrates as determinants and indicators of soil quality," American Journal of Alternative Agriculture, vol. 7, no. 1-2, p. 38, 1992.

[13] C. Menta, "Soil fauna diversity-function, soil degradation, biological indices, soil restoration," in Biodiversity Conservation and Utilization in a Diverse World, G. A. Lameed, Ed., IntechOpen, London, UK, 2012.

[14] P. C. Oguike and J. S. C. Mbagwu, "Variations in some physical properties and organic matter content of soils of coastal plain sand under different land use types," World Journal of Agricultural Sciences, vol. 5, no. 1, pp. 63-69, 2009.

[15] W. Zhou, T. F. Lv, Y. Chen, A. P. Westby, and W. J. Ren, "Soil physicochemical and biological properties of paddy-upland rotation: a review," The Scientific World Journal, vol. 2014, Article ID 856352, 8 pages, 2014.

[16] L. T. Nanganoa and J. N. Njukeng, "Phosphorus speciation by 31P NMR spectroscopy in leaf litters and crop residues from para rubber, cocoa, oil palm, and banana plantations in the humid forest zone of Cameroon," Journal of Applied Chemistry, vol. 2018, Article ID 6290236, 8 pages, 2018.

[17] FAO-UNDP/ONAREST, "Soils and soil fertility management of lands of the Ekona Banana Estate," Technical Report no. 11, Cameroon Development Corporation (CDC), Ekona, Cameroon, 1980. 
[18] G. R. Blake and K. H. Hartge, "Bulk density," in Methods of Soil Analysis, Part 1-Physical and Mineralogical Methods, A. Klute, Ed., pp. 363-58, American Society of Agronomy-Soil Science Society of America, Madison, WI, USA, 2nd edition, 1986.

[19] G. W. Gee and J. W. Bauder, "Particle size analysis," in Methods of Soil Analysis, Part 1, A. Klute, Ed., pp. 383-411, American Society of Agronomy-Soil Science Society of America, Madison, WI, USA, 2 edition, 1986.

[20] S. J. Fleischer and W. A. Allen, "Field counting efficiency of sweep-net samples of adult potato leafhoppers (Homoptera: Cicadellidae) in Alfalfa," Journal of Economic Entomology, vol. 75, no. 5, pp. 837-840, 1982.

[21] R. Rozieta, A. R. Sahibin, and I. Wan Mohd Razi, "Physicochemical properties of soil at oil palm plantation area, Labu, Negeri Sembilan," in Proceedings of AIP Conference Proceedings, vol. 16781, article 020031, Rome, Italy, September 2015.

[22] N. C. Brady and R. R. Weil, The Nature and Properties of Soils, Prentice-Hall, Upper Saddle River, NJ, USA, 13th edition, 2002.

[23] K. Fujii, "Soil acidification and adaptations of plants and microorganisms in Bornean tropical forests," Ecological Research, vol. 29, no. 3, pp. 371-381, 2014.

[24] M. Emadi, M. Emadi, M. Baghernejad, H. Fathi, and M. Saffari, "Effect of Land use change on selected soil physical and chemical properties in North Highlands of Iran," Journal of Applied Sciences, vol. 8, no. 3, pp. 496-502, 2008.

[25] C. Guilser, "Effect of forage cropping treatment on soil structure and relationship with fracta dimensions," Geoderma, vol. 131, no. 1-2, pp. 33-44, 2006.

[26] U. C. Osakwe and C. A. Igwe, "Conversion of forests to arable land and its effect on soil physical properties in Enugu State South Eastern Nigeria," Nigerian Journal of Biotechnology, vol. 26, pp. 33-40, 2013.

[27] T. Bizuhoraho, A. Kayiranga, N. Manirakiza, and K. A. Mourad, "The effect of land use systems on soil properties; a case study from Rwanda," Sustainable Agriculture Research, vol. 7, no. 2, pp. 30-40, 2018.

[28] A. Salehi, N. Ghorbanzadeh, and E. Kahneh, "Earthworm biomass and abundance, soil chemical and physical properties under different poplar plantations in the north of Iran," Journal of Forest Science, vol. 59, no. 6, pp. 223-229, 2013.

[29] R. Lal, "Effects of macrofauna on soil properties in tropical ecosystems," Agriculture, Ecosystems and Environment, vol. 24, no. 1-3, pp. 101-116, 1988.

[30] D. A. Neeher, "Soil community composition and ecosystem processes; comparing agricultural ecosystems with natural ecosystems," Agroforestry Systems, vol. 45, pp. 159-185, 1999.

[31] Y. I. Menedez and G. Cabrera-Davila, "Litter macrofauna in two systems with different land use and husbandry in Cuba," Cuban Journal of Agricultural Science, vol. 48, no. 2, pp. 181-188, 2014.

[32] M. A. Altieri, "The ecological role of biodiversity in agroecosystems," Invertebrate Biodiversity as Bioindicators of Sustainable Landscapes, vol. 74, no. 1-3, pp. 19-31, 1999.

[33] J.-F. Ponge, G. Pérès, M. Guernion et al., "The impact of agricultural practices on soil biota: a regional study," Soil Biology and Biochemistry, vol. 67, pp. 271-284, 2013.

[34] S. T. d. Souza, P. C. Cassol, D. Baretta et al., "Abundance and diversity of soil macrofauna in native forest, eucalyptus plantations, perennial pasture, integrated crop-livestock, and no-tillage cropping," Revista Brasileira de Ciência do Solo, vol. 40, article e0150248, 2016.
[35] E. T. Mongyeh, K. J. N. Ndamukong, and J. N. Okolle, "Effects of insecticides with different modes of action in the control of banana weevils (cosmopolites sordidus) in Cameroon," Journal of the Cameroon Academy of Sciences, vol. 12, no. 1, pp. 1-9, 2015.

[36] J. Okolle, I. Mumah, N. Christopher, L. Nanganoa, O. Doungous, and A. Fongod, "Role of combined ash and terbuphos as preplanting corm treatment to manage corm borer weevils (cosmopolites sordidus) on plantains and stimulate growth," Journal of Experimental Agriculture International, vol. 22, no. 3, pp. 1-12, 2018.

[37] C. Gol, "The effects of land use change on soil properties and organic carbon at Dagdami river catchment in Turkey," Journal of Environmental Biology, vol. 30, no. 5, pp. 825-830, 2009.

[38] M. A. Hajabbasi, A. Jalalian, and H. R. Karimzadeh, "Deforestation effects on soil physical and chemical properties, Lordegan, Iran," Plant and Soil, vol. 190, no. 2, pp. 301-308, 1997.

[39] A. Cerdà and M. F. Jurgensen, "The influence of ants on soil and water losses from an orange orchard in eastern Spain," Journal of Applied Entomology, vol. 132, no. 4, pp. 306-314, 2008.

[40] N. Karmegam and T. Daniel, "Effect of physico-chemical parameters on earthworm abundance: a quantitative approach," Journal of Applied Sciences Research, vol. 3, no. 11, pp. 1369-1376, 2007. 

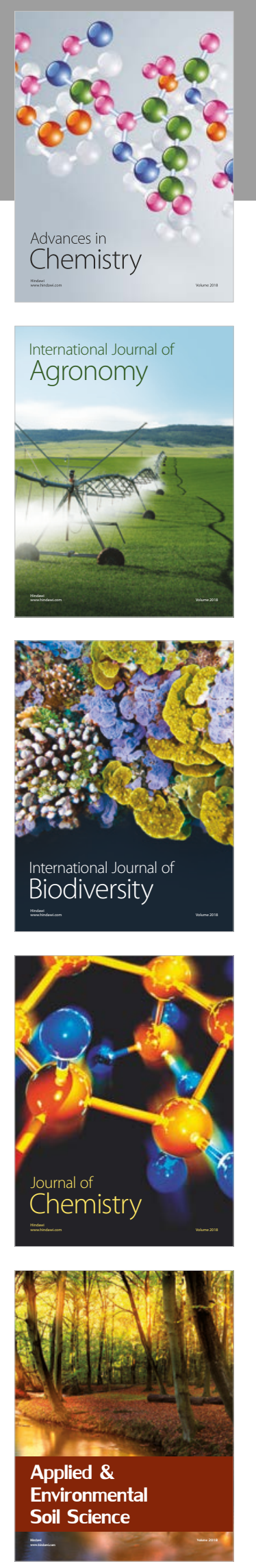

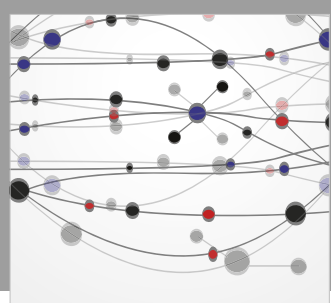

The Scientific World Journal

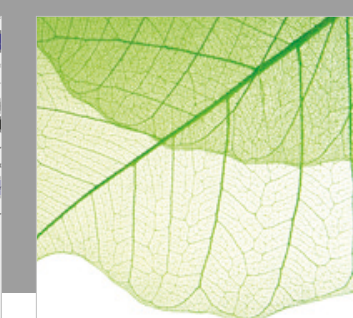

Journal of Botany

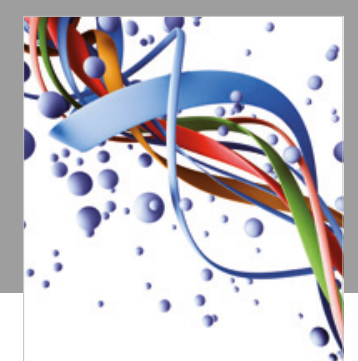

Scientifica

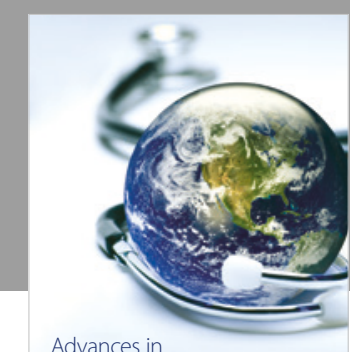

Public Health

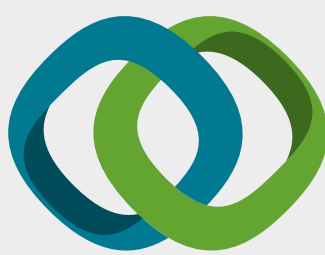

Hindawi

Submit your manuscripts at

www.hindawi.com
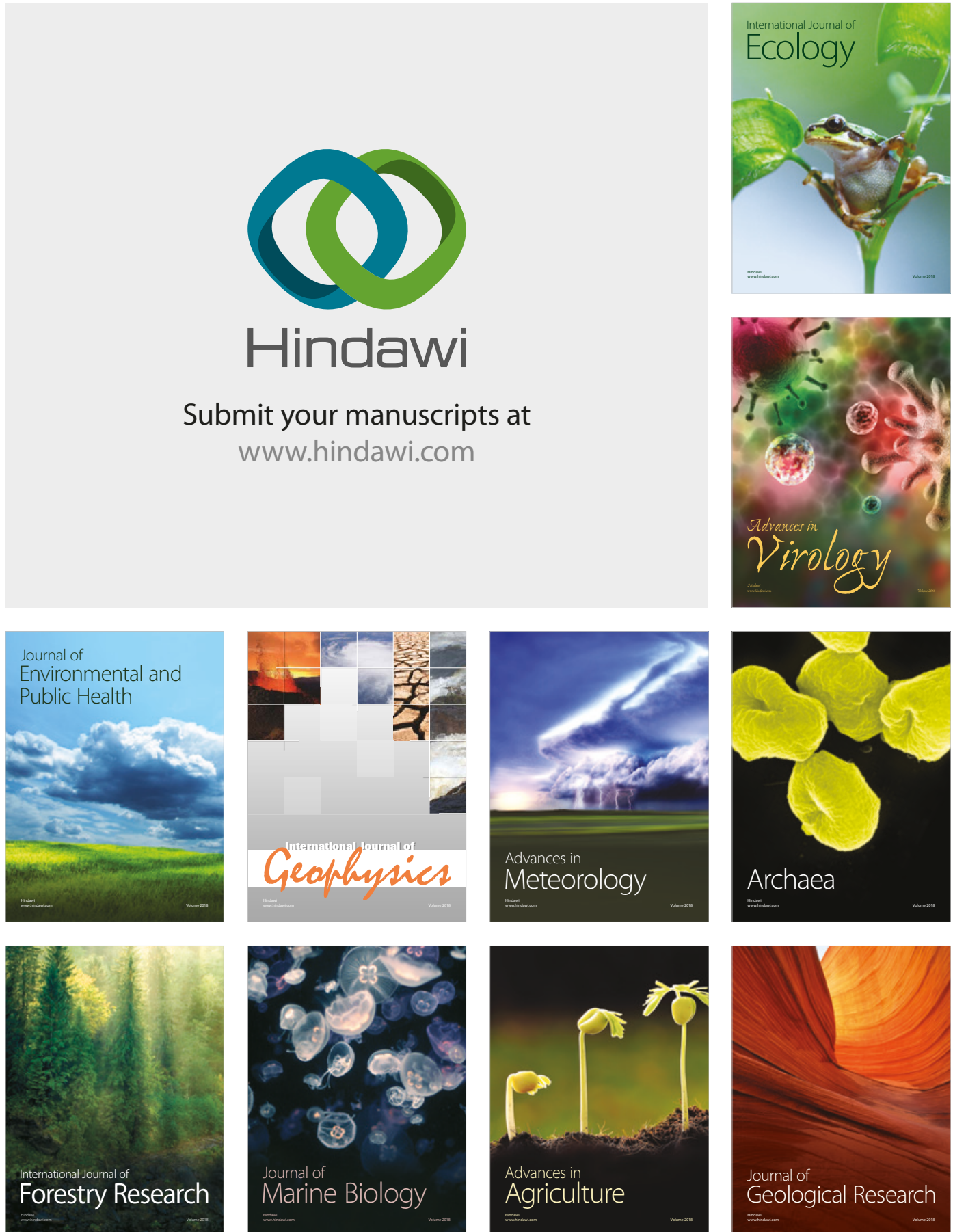

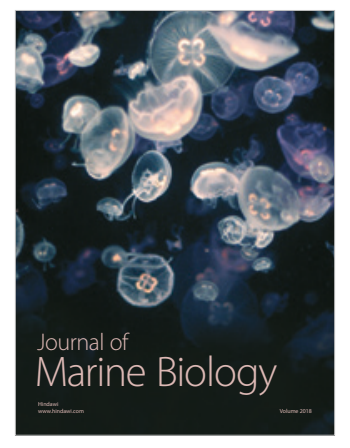

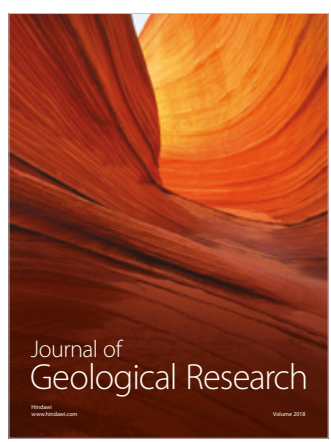

